\title{
Contemporary Substance Use in Guyana: The Prison Context ${ }^{1}$
}

\author{
Tammy C. Ayres ${ }^{2}$, Queenela Cameron ${ }^{3}$, Kristy Warren ${ }^{4}$ and Dylan Kerrigan 5
}

\begin{abstract}
Substance use in contemporary Guyana cannot be dismantled from the historical introduction and control of substances across the British Empire, and this is true in the community as it is in prison. In a form of transhistorical repetition, some of the substances being used have changed since colonial times, but many have also stayed the same, as have the reasons for their use. This paper follows on from 'the History of Substance Use and Control in British Guiana' (Moss and Toner, 2020) and explores semi-structured prisoner interviews among a group of male prisoners, which shows that substance use in prison - as in the community - is often a coping mechanism, as well as a way to pass time, escape and alleviate the pains of imprisonment. In this sense substance use is an adaptive strategy to the micro level experiences of transhistorical processes, such as social control, the development of class and ethnic politics, and were central to the nexus of exploitative social and labour relationships on colonial plantations.
\end{abstract}

Keywords: Contemporary Substance Use, Prisons, Guyana, Guyana Prison Service.

\section{Introduction}

The historical introduction and control of substances across the British Empire cannot be dismantled from the substances used in those ex-colonies today. The history of substances and their consumption was integral to the establishment of empire and global capitalism, as has been their control and prohibition (see Ayres, 2020a, 2020b; Courtwright, 2001; Farrell, 1997; Paley, 2014). In a form of transhistorical repetition, drugs are continually seen by authorities as subverting capital, undermining morality, and the dominant status quo, alongside causing crime, destroying communities and individuals. In fact, drugs - their use and supply - are routinely presented as a significant causal factor in a range of societal problems rather than a symptom of wider social problems (see Ayres, 2019, 2020a; Taylor, Buchanan and Ayres, 2016), and Guyana is no different.

\section{Historical Context}

Historically, substances in Guyana were used to control indigenous populations, supress emotional and physical pain, and facilitate work in extremely harsh conditions and were also

\footnotetext{
1 This paper is based on research conducted for the ESRC-funded project Mental Health, Neurological and Substance Abuse (MNS) Disorders in Guyana's Jails: 1825 to the present day (award no. ES/S000569/1). This project is a collaboration between the University of Guyana and the University of Leicester, in partnership with the Guyana Prison Service. The project brings into dialogue researchers in History, Criminology, Sociology and Literature. It takes both a multi-disciplinary and interdisciplinary approach to key questions about the form, function, and experience of incarceration, encompassing inmates and the people who work with them. It encompasses both the British colonial period, and the era since Guyana's independence in 1966.

${ }^{2}$ Associate Professor, Department of Criminology, University of Leicester, Leicester, UK. Email: tca2@le.ac.uk. ORCID: 0000-0002-2590-9558.

3 Lecturer, Department of Government and International Affairs, University of Guyana, Guyana. Email: queenela.cameron@uog.edu.gy.

${ }^{4}$ Research Associate, School of History, Politics and International Relations, University of Leicester, Leicester, UK. Email: kw272@le.ac.uk. ORCID: 0000-0001-6790-4010.

${ }^{5}$ Lecturer, Department of Criminology, University of Leicester, Leicester, UK. Email: dk252@1e.ac.uk. ORCID: 0000-0003-2453-9804.
} 
central to the nexus of exploitative social and labour relationships on colonial plantations (see Moss and Toner, 2020). Little has changed. The consumption and control of substances was functional in colonial times and remains functional today. Some of the contemporary reasons provided for using drugs also echo those given during colonial times (e.g., self-medication, solidify bonds, idleness, relieving stress, hedonism, to help concentration and enhance an activity or feeling) (Anderson 2015; GDIN, 2017; Henry, 2017; Moss and Toner, 2020).

Across the globe, substances have always been used to temper the material needs reflective of the era. This remains true in contemporary society. Whether it is the consumption of a glass of wine after work or a prescribed antidepressant or antianxiety medication. Substance use is about coping with contemporary life and its subsequent lifestyles, with all of the strains, pressures and demands it places on people (Ayres, 2017, 2019, 2020a). What changes pertains to the classification of substances: whether they are seen as "drugs" or "nondrugs". For example, some substances - alcohol and tobacco - occupy a privileged position that is not underpinned by scientific evidence or reason, but shapes societies reaction to them by deciding who we treat and who we punish. This acts as a form of social control that disproportionately discriminates along the lines of race/ethnicity, class and gender (see Taylor et al. 2016).

\section{Substance Use in Guyana}

According to the Guyana Drug Information Network (GDIN), alcohol and tobacco are used across Guyana more widely than illicit drugs, with both legal substances having a lower age of onset than illicit drugs (17.7 and 18.7 respectively). Cannabis is the most widely used illicit drug in Guyana, with $1.9 \%$ smoking it daily, and has the lowest age of onset (18.9 years) of all drugs, which is followed by crack cocaine, cocaine hydrochloride and finally ecstasy (GDIN, 2017; Henry, 2017). Drugs like ecstasy and cocaine can also be put in a cannabis joint and smoked (black cigarettes), although the numbers reporting these practices are very small (0.21$0.42 \%)$ (GDIN, 2017).

There also appears to be a link between substance use and crime, that not only pervades history, but is also illustrated in contemporary figures from Guyana. The figures show that for some substance-using prisoners there appears a connection between their substance use and criminality, with a small minority reporting committing crime to pay for their drugs (GriffithWills, 2010: 5). However, these findings should be treated with caution. The likelihood here is that persons commit crime to pay for most things, and drugs is just one of the things they buy. For International evidence suggests cannabis is not linked to crime, even psychopharmacologically, bar crimes arising from prohibition (see Pederson and Skardhamar, 2010). Furthermore, the likelihood of being arrested for drugs is disproportionate across social class differences (Sarsfield and Bergman, 2017).

The use of substances for spiritual and medical reasons, which is still the case in contemporary Guyana, has an even longer history. Although the link between substance use and crime pervades history. A small percentage of Guyanese $(2.9 \%)$ use cannabis to treat mental illness or a recognised medical condition, which include 'asthma, pneumonia, cold, pain, malaria, glaucoma and diabetes', and the majority (51.5\%) use it to treat asthma (GDIN, 2017). Evidence also suggests that cannabis is a risk factor for bronchial asthma and smoking cannabis should be avoided among asthmatics (Bramness and von Soest, 2019). A lot of Guyanese (43.5\% of respondents) think cannabis should be allowed for medical and therapeutic purposes, while $17.4 \%$ agreed it should be permitted for religious purposes (GDIN, 2017). 
Some do not see cannabis as a drug, let alone a risky and dangerous drug; instead, they see cannabis as a 'natural herb' (Henry, 2017).

Adverse effects reported by those who used drugs included memory loss (10.5\%), domestic problems $(13.5 \%)$, getting involved in arguments or fights $(8.9 \%)$, self-harm $(4.6 \%)$ and suicidal ideation (6.8\%). Being taken advantage of sexually (3.6\%) and taking sexual advantage of someone else (3.5\%) was also reported (GDIN, 2017), alongside drug facilitated sexual assaults (Henry, 2017). This supports other evidence suggesting the use of alcohol and drugs has increased in Amerindian villages and contributed to social issues like violence (GUYDIN, 2018). Other anecdotal evidence suggests cannabis and crack use among poor indigenous communities in economic decline, with high unemployment creates conditions for increases in violence, self-harm, suicide, sexual abuse, teenage pregnancy and trafficking in persons (Guyana Times, 2017). However, there is a dearth of information on this topic.

The most popular substances among the general population are also the most popular substances among those with more problematic patterns of substance use/dependence like those accessing drug treatment and/or prisoners. However, evidence suggests that those in the general population who smoke cannabis regularly had a number of strategies to manage their use to ensure it did not become problematic and/or impact negatively on their life (e.g., they did not smoke it before midday or when they were alone). The majority also indicated they had previously, albeit unsuccessfully, tried to reduce their cannabis use (GDIN, 2017). In fact, over half $(51.6 \%)$ of those that had used cannabis in the last year were identified by the Cannabis Abuse Screening Test (CAST) to be at a high risk of problematic use (GDIN, 2017).

Drugs are prohibited in Guyana, and up until recently, Guyana's approach has been described as 'draconian' 'discriminatory', 'outdated' and 'unjust' (CARICOM, 2018). It also means, users are reluctant to access drug treatment services as they would also be disclosing a criminal offence, which is punishable by imprisonment. Cannabis users in Guyana still face a mandatory prison sentence of three-years for the possession of one cannabis cigarette, which explains why Guyana's jails are overcrowded with non-violent drug offenders (see Ayres, 2020c; Ifill, 2019). The arrest rate in Guyana for illegal drugs is 96 per 100,000 inhabitants (Klein et al. 2013). In 2017, of the 262 people charged with possession, the majority was for cannabis $(93 \%)$ followed by cocaine $(7 \%)$, and while 423 persons were charged with drug trafficking, the majority was again for cannabis $(88 \%)$ and cocaine $(12 \%)$ (GUYDIN, 2018). This indicates that the most popular illicit substances in Guyana both in terms of use and supply is cannabis, regardless of age, although there is some indication other substances are also used - like ecstasy - but to a much lesser extent (GDIN, 2017; GUYDIN, 2018; Henry, 2017).

\section{Substance Use in Prison}

Prisoners in Guyana have a higher rate of substance use than the general population, and particularly problematic patterns of use, reflecting wider trends across the globe. According to a 2017 IDB report, a third (22.7\%) of prisoners in Guyana admitted to using alcohol and/or drugs in the last month while in prison, with the majority using cannabis (84\%) and alcohol (33\%) (Sarsfield and Bergman, 2017). While a lot of prisoners bring their substance use habit from life before prison, the international evidence also suggests drug use, particularly problematic drug use, is also often initiated in prison, and this is linked to higher rates of selfharm and suicide, mental illnesses including personality disorders, bullying, violence, debts, medical emergencies and treatment, while drug using offenders also have higher recidivism and mortality rates than non-drug users and non-drug using criminals (Boys et al. 2002; Fazel et al. 2016; Indig, Gear and Wilhelm, 2016; PRT, 2020). 
This is also true of prison staff, as working inside a prison is associated with high levels of mental ill-health, abuse, violence, substance use and burnout (Kilman et al. 2015). Higher rates of mental health problems and burnout negatively impacts on staff recruitment, staff retention, staff turnover, sickness and absenteeism, which can be seen in the Guyana Prison Service being described as a 'highly stressful and dangerous environment' by Jemmott (2016). Prison personnel in Guyana are routinely threatened and forced to deal with traumatic experiences (Ifill, 2019; Jemmott, 2016) that often arise from merely doing their job, but which can lead to lasting and irreversible trauma that may also initiate staff use of substances to cope.

Recently, the seizure of contraband that included cannabis, rum and a cell phone, led to prison rioting and a fire (Garnett, 2020), while in 2016 prisoners set fire to Georgetown Prison, which killed 17 prisoners and was also attributed, among other things, to a seizure of contraband (Wilkinson, 2016). Both incidents were also attributed to frustrations caused by long remand times and to prison overcrowding caused by the implementation of custodial sentences for the possession of cannabis (Ayres, 2020c; Garnett, 2020; Ifill, 2019; Starbroek News 2020; Wilkinson, 2016). Therefore, the ensuing discussion explores the use of substances by prisoners in contemporary Guyana to show they are functional because they act as a form of self-medication and provide men with an effective coping strategy that not only pertains to being in prison, but also relates to the social class punishment of their lives more generally.

\section{Methodology}

This paper draws on 20 semi-structured interviews with prisoners that lasted between 60 to 90 minutes, and 6 semi-structured interviews with prison personnel that lasted between 40 to 64 minutes. Participants were recruited using a convenience sampling strategy; the researchers selected prison personnel available and willing to participate, while the Guyana Prison Service chose the individual prisoners to be interviewed. Ten of the prisoners were clinically assessed with MNS disorders, and the other ten not diagnosed with MNS disorders. A semi-structured interview protocol designed to capture a limited life history from each participant was developed and used, and ethical approval was received from the University of Leicester Ethics committee. All of the participants were provided with consent forms and information sheets, which were explained to all prisoners in front of the prison welfare officer due to varying levels of literacy. All interviews were transcribed and then thematically open coded. A second process of coding is ongoing currently via the software NVIVO. This working paper discusses some of the preliminary findings that have emerged so far, about substance use in the context of prison.

\section{Substance Use in Prison}

All of the men interviewed who used substances in prison had used substances outside of prison, meaning they imported their substance use into the prison with them, alongside other behaviours, friendships and cultural practices (e.g. religion). However, there was also evidence in their life stories that substance use was also a response to prison, including the pains arising from imprisonment (Sykes, 1958).

The men we spoke to were mostly Afro-Guyanese, from economically deprived backgrounds, had dropped out of education and were in prison for a range of offences that varied from the possession of cannabis to murder. The men talked about falling into substance use and supply, and selling cannabis to make money and to supplement their income - 'I was doing taxi so I was looking for some extra bucks, I was doing some cannabis they call it weed and that what get me here'. 
In line with the link between substance use and crime, some of the murders, according to the men's own accounts, were committed while drunk or intoxicated on drugs, which was also true of the assault-related offences, particularly domestic violence (see Cameron, 2020). In fact, according to the men, alcohol seemed to be more strongly connected to violent crimes than any other substance. While most of the men talked about cannabis and tobacco making prison life easier, some men also talked about the brewing and drinking of homemade fermented wine - Kushung Peng/Cushypen - in prison. Interestingly, the men reported that cannabis and tobacco were of a comparable price in prison and were readily available but were reliant on supplies coming in from outside, whereas the men brewed their own alcohol out of fruit and food scraps in the prison.

Cannabis we were told by a number of participants, allowed the men 'to relax, lie down, get some rest,' as well as provide a little light relief and recreation. It also was used for everyday functions including managing emotions as well as coping with the conditions of imprisonment - 'It helps me to eat, helps me to rest, sometimes it helps me to calm down'. The men also mentioned how they controlled their substance use, so it did not become more problematic, while others talked about giving drugs up once they were released. In fact, one man acknowledged that he hoped he did not change his mind about giving up cannabis when he was finally released.

Although most of the men said that violence was rare in prison - both against staff but also between prisoners - there was some evidence from both the men and the staff of a link between substance use and disruptive - even psychotic - behaviour if people did and did not have substances. Some of the staff talked about the home made alcohol inducing hallucinations and making the men disruptive and violent, while some of the men talked about their fellow prisoner's behaviour if they did not have substances - 'when some people don't have it you know the behaviour, when they have it you hardly see them, and when they don't have it you would hear them and see them' - as well as the consequences when they had had too much of the substance and were intoxicated - 'they get ill, they get high, vomit up, curse up'. There was also some indication from the professionals/practitioners in Guyana that substance use, specifically cannabis, and to a lesser extent crack and the fermented alcohol, was connected to mental ill-health, particularly psychosis, although the exact relationship underpinning this connection requires further investigation and is at present unclear. What is clear, is that those suffering from cannabis induced psychosis were also prevalent in the psychiatric hospital, illustrating this is clearly an issue facing practitioners in Guyana.

Some of the men talked about the staff turning a blind eye to cannabis in prison as it made for a quieter jail. However, it was unclear how true or accurate this was, particularly since cannabis is illegal and some of the more recent prison riots in Guyana have been attributed to prisoners protesting against the confiscation of contraband, which included mobile phones and drugs (Garnett, 2020; Jemmott, 2016; Starbroek News 2020; Wilkinson, 2016). In fact, what is clear from the international evidence, which also seems to be true in Guyana, is that substances (supply and use) in prison are clearly linked to violence, bullying, debts, mental-ill health, self-harm and suicide. These all have a negative effect on the prison environment as well as the people living and the working inside the prison, creating and/or exacerbating an already harmful/challenging environment. These factors also undermine the men's rehabilitation and future reintegration, which may continue to involve substance use.

\section{Conclusions}


The preliminary findings arising from the current research suggest that substance use is a coping mechanism that many of the men in this research used to deal with their everyday lives both outside of prison as well as in prison for the pains of their imprisonment. In this sense substance use is an adaptive strategy to the micro level experiences of transhistorical processes, such as social control, the development of class and ethnic politics, and were central to the nexus of exploitative social and labour relationships on colonial plantations.

Although some of the substances being used have changed since colonial times, many have also stayed the same (e.g., rum/alcohol and cannabis). The substances being used in the community are also the substances being used in prison, although at higher rates, which makes sense because prison walls are only designed to keep people inside and others out. It also illustrates that despite high levels of security, they are not total, but rather porous institutions. The are also inept at stopping the cultures of intoxication and substance-use that develop in response to the social structures of colonialism and racial capitalism. Alcohol and cannabis were popular in colonial times and they still are in Guyana today. Their continued use, and the consequences suffered by certain social classes more than others due to their consumption is a reflection that colonialism and Empire continues to shape the present.

\section{Acknowledgements}

The authors would like to thank Jamie Banks for his comments on an earlier draft.

\section{References}

Anderson, C., 2015. After emancipation: Empires and imperial formations. In Hall, C., Draper, N., \& McClelland, K. (Eds.) Emancipation and the remaking of the British imperial world. Manchester: Manchester University Press.

Ayres, T.C. (2020a). Substances: The luxurious, the sublime and the harmful. In S. Hall, T. Kuldova \& M. Horsley (Eds.), Crime, Harm and Consumerism (pp108-122). London: Routledge.

Ayres, T.C. (2020b). The War on Drugs and Its Invisible Collateral Damage: Environmental Harm and Climate Change. In A. Brisman and N. South (Eds.), Routledge International Handbook of Green Criminology (pp 239-259). London: Routledge.

Ayres, T.C. (2017) Drugs, Leisure, Consumption and Harm, BSC newsletter (winter): 20-26.

Boys, A., Marsden, J. and Strang, J. (2001) Understanding Reasons for Drug Use Amongst Young People: A Functional Perspective, Health Education Research, 16(4), 457-469.

Bramness, J.G. and von Soest, T. (2019) A longitudinal study of cannabis use increasing the use of asthma medication in young Norwegian Adults. BMC Pulmonary Medicine, 19(52): 17.

Courtwright, D. (2001) Forces of Habit: Drugs and the Making of the Modern World. Cambridge: Mass.

Farrell, A. (1997) Addicted to Profit: Capitalism and Drugs. International Socialism, 77:

Garnett, T. (2020) Seizure of Contraband Led to Prison Riot. Guyana Chronicle, $14^{\text {th }}$ July.

Griffith-Wills, M.F. (2010) Study on Alcohol and Drugs in the Young Offender Population. Guyana: NANA. 
Guyana Times (2017) Drug Abuse in Indigenous Communities. $19^{\text {th }}$ November.

Henry, C. (2017) Rapid Situation Assessment of Drug Use in Guyana.

Klein, A., Day, M. and Harritt, A. (2013) Caribbean Drugs. London: Zed Books.

Ministry of Public Security (2016) Guyana Drug Information Network (Guydin) 2015 Annual Report. Guyana: Crime and Social Observatory.

Paley, D. (2014) Drug War Capitalism. Edinburgh: AK Press.

Pedersen, W. and Skardhamar, T. (2010) Cannabis and crime: findings from a longitudinal study. Addiction, 105(1): 109-118. doi:10.1111/j.1360-0443.2009.02719.x

Taylor S, Buchanan J and Ayres TC (2016) Prohibition, privilege and the drug apartheid: The failure of drug policy reform to address the underlying fallacies of drug prohibition. Criminology and Criminal Justice 16(4): 452-469. 